\title{
5 Added value capturing in Switzerland
}

\section{How much is enough?}

\author{
François-Xavier Viallon
}

\section{Institutional determinants of economic land value}

In Western conceptions of land property, the concept of economic land value can be traced back to Roman times, when it was defined in the three components of property: in the usus and in the fructus, i.e. in the use(s) that one can make of its property and the subsequent value one can gain from these uses; and in the abusus, i.e. in the right to sell and destroy property, and in the added or reduced value that results from the exercise of this right.

In the modern conception of land property, economic land value is conditioned by two broad institutional factors. The first one is the property rights system. Through a set of instruments, such as acquisition, sale, and mortgage of land, property rights make the circulation of capital through land possible, and, in addition, grant a financial leverage to the property titleholder, which can be reinvested (Harvey 1982). The second institutional factor is public policy. Through zoning and land service, land use planning policy defines development rights to landowners, and ensures the accessibility and effective usability of the land. Other public policies also influence the economic value of land. Through the variation of tax rates, fiscal policy makes specific locations more or less attractive for inhabitants and companies. Further, the construction of transport infrastructure increases the value of nearby land (e.g. Cervero and Murakami 2009). The point is that value creation on land is widely conditioned by public planning and action, and tightly intertwined with the property rights system. Therefore, value capture does not only refer to the levy of the increment in land value caused by planning decisions, but questions more broadly the appropriation of land rent.

This contribution analyses two value capture instruments of Swiss land policy and their influence on land management. The argument is divided into three parts. The first part reviews existing value capture instruments in Swiss land policy on federal and cantonal level and presents recent legal changes. The second part presents two examples of value capture tools in practice, focusing on the strategies pursued by authorities, and the means they have in order to implement these tools. The third parr discusses the potential of value capture instruments in order to achieve a more sustainable use of land, 


\section{François-Xavier Viallon}

considering their practicability, efficacy, efficiency, and legitimacy. It turns out that resource use and value control are intertwined and should be coordinated over time in order to use land sparingly and satisfy societal needs.

\section{Overview of value capture instruments in Switzerland}

Referring to the criterion of time, one can classify value capture instruments into two categories. The first category encompasses punctual value capture instruments stemming from the federal spatial planning act and the cantonal planning and construction acts. These instruments are linked with a zone change or the attribution of additional development rights to a plot and the effective use of these rights by landowners and developers. The second category refers to durative value capture instruments. These capture on a recurrent basis (annually) part of the land rent, and thus constitute a land use steering tool that public actors can use for achieving land policy goals. These instruments are mostly defined in cantonal and communal fiscal legislation.

\section{Punctual value capture instruments}

A preliminary remark emphasising the intertwine of public policies and property rights eschewed previously is that value capture tools from land policy discussed thereafter are secured by a legal mortgage, that is to say, a property rights obligation in favor of the concerned authority securing the payment of the due value capture. In Swiss law, a legal mortgage is prioritised to all other mortgages and generally does not require to be entered into the land registry.

\section{Tax on added land value created by zoning}

The main value capture instrument of Swiss land policy is the tax on added land value created by zoning. The first spatial planning act proposal elaborated in 1974 introduced the instrument in order to separate planning from property issues (Nahrath 2005). The idea was to create a federal compensation mechanism that captured part of the value induced by the definition of new building zones in order to compensate their reduction elsewhere. The funds collected by the instrument were meant to grant authorities the means to distribute, remove, and relocate development rights without infringing the guarantee of ownership, which prescribes that, under specific conditions defined by case law, a full compensation is due to the landowner from whom authorities remove development rights. Without such compensation mechanism, authorities would have been limited in the fulfilment of land policy objectives - such as the dimensioning of building zones according to societal needs, and their rightful location, because they could not have undone past zoning choices. 
However, the 1974 legal proposal was rejected after the referendum launched by federalist milieus and economic interests linked to real estate and construction. The spatial planning act adopted in 1979 left the implementation of the tax on added land value to the cantons, that is to say to the member states of the Swiss Confederation. Over the past 35 years, only 4 of 26 cantons implemented the instrument:

- The city canton Basel introduced a tax on added land value created by zoning in 1977 and uses it today. It applies a uniform 50 percent tax rate on the difference between old and new land market values, both to new building zones and to up-zoning changes. The amount of funds collected varies depending on the construction activity, as the tax is only due when landowners or developers effectively use the granted rights. The funds collected are intended for surrounding green spaces, and thus indirectly benefit both the investor and inhabitants (Poldervaart 2016).

- Canton Bern implemented in its cantonal law the tax on added land value in 1985. However, the canton delegated its implementation to the communes, also on a voluntary basis. The research results of the instrument's implementation in canton Bern are shown further later in this chapter.

- Introduced in 1986, the tax on added land value created by zoning in Neuchâtel taxes 20 percent of the added value creared through the planning measure. The funds collected are used to compensate reduced values created through planning, help farmers to acquire land, or for land use planning measures decided by the canton or the communes. The time of taxation is decided by the cantonal administration, but occurs at the latest when the plot is sold.

- In Geneva, the tax was introduced in 2011 and fixed a tax rate of 15 percent that applies only to new building zones. The money collected is primarily dedicated to housing and compensation measures resulting from planning decisions. A lump sum discount rate of 30 francs per square meter is granted in the calculation of the added economic value created through zoning. Note that in specific zones, land price calculation does not refer to market value, as in specific zones, land prices and rents are capped by law.

Since the 2014 revision of the federal spatial planning act (SPA), the tax on added land value created by zoning has become mandatory in all cantons. In case of non-implementation, no new zoning operations are allowed (art. 38a SPA). The minimal taxation rate has been set at 20 percent of the added land value (art. 5 SPA). The tax is due when the land is developed or sold. The tax produce is mainly destined to compensations due to planning measures that are equivalent to an expropriation, but also to the protection of fertile land, and to the better use of existing building zones including brownfields and low-density zones. A consultancy estimated that 
a 20 percent tax rate on new building zones will generate around 2 billion francs per year in Switzerland (BSS 2011).

\section{Extended land service tax}

In Switzerland, as opposed to the tax on added land value, land service taxes are conceived as value recovery tools. Federal spatial planning legislation sets the objective of making the landowners financially participate to land service from which they gain specific and particular advantages. Most cantonal laws have a set of instruments that allow communes to recover the investments made in land service such as roads, water and sewer connection, electricity, street lights, and so forth. Other public infrastructure that does not only service specific plots, such as schools, sports facilities, bus stops, and green spaces, are generally financed through the produce of regular taxation.

However, from the 1980 s onward, certain communes in canton Vaud, when they granted new or additional development rights to a plot, started negotiating informally with developers for a lump sum agreement financing public infrastructure beyond land service, such as green spaces and parks, bus stops, and schools. In 2007 , the developer of a wider project refused to pay the sum the commune claimed, arguing that there was no legal basis (Berta 2016). The tribunal proved him right, arguing that the contractual capture of added value required the commune to allocate the money to specific infrastructure, and not just put it aside for undefined purposes of public planning or the realisation of public infrastructure, as the commune partly did.

Consequently, the cantonal law was changed in 2011: it formalised communal practices through the introduction of a specific instrument in the cantonal law on communal taxes called extended land service tax. On average, urban communes that use the instrument tax around 30 francs for each additional square meter of gross floor area dedicated to activities and 140 francs per square meter for housing. ${ }^{2}$ The tax difference between distinct uses is explained by the additional infrastructure housing requires (such as day care centers and schools). The target groups are all landowners, with the exception of authorities, churches, and private landowners pursuing an aim of public interest. The maximum sum to be taxed is capped at 50 percent of construction cost of public infrastructure linked to the zoning operation. These are, in decreasing order of costs: schools, kindergartens, bus stops and other transport related infrastructure, green spaces. The controversy that appeared while applying the tax to (semi-)public landowners is illustrated later in this section.

Since the 2014 federal revision of the spatial planning act and the obligation to implement the tax on added land value created by zoning, canton Vaud has two levies for taxing value increments due to zoning. Current cantonal legislative proposal has limited the combined taxation rate of 
both instruments to 50 percent of the added value created by the zoning operation.

Although not presented in detail here, other punctual fiscal tools taxing transactions exist: a real estate gains tax, which is digressive over time (from a 50 percent tax rate for less than two years possession in canton Geneva, to less than 5 percent for 20 years possession) and a property transfer tax (generally between 1 and 3 percent of the transaction price). Inheritance tax is almost nonexistent.

\section{Permanent value capture instruments}

A consultancy estimates that approximately 18 percent ( 14.5 billion francs) of all fiscal revenues in Switzerland (82 billion francs in 2006) are linked to land and real estate (Wüest und Partner 2006). Two main instruments (and a set of fiscal deductions not presented here) allow capture value:

- The land property tax (a wealth tax specific to land property), ${ }^{3}$ which accounts for roughly 16 percent of land-linked revenues ( 2.3 billion francs);

- The land property income tax, which is mostly collected through the regular income tax or benefits tax, and accounts for 84 percent of landlinked revenues (12.2 billion francs).

\section{Land property tax}

The land property tax taxes annually the value of plots. It is defined by cantonal legislation -6 of 26 cantons do nor have such instrument at all (Waltert et al. 2010). The tax relies on the official land value, which in most cantons is underrated: these can refer to the acquisition price - notwithstanding the date of acquisition, or to an irregularly adjusted, and in most cases significantly underrated, but still updated land value (see for example Steuerverwaltung des Kantons Bern 2009). Taxation rate is usually defined in per mill of the land's value.

\section{Land property incone tax}

Depending on cantonal and communal tax rates, but also between natural and legal persons, income taxation varies substantially from 13 percent to 36 percent of the yield (Wüest und Partner 2006). Certain moral persons with special statuses benefit from a negotiated tax. Further, a wide range of organisations are exempted from the land property income tax: authorities, churches, national pension funds, health care funds, and other organisms pursuing goals of public interest or nonprofit goals. When declaring the income earned through real estate, landowners and investors subtract maintenance cost and interest paid on mortgages from the declared revenue. 


\section{François-Xavier Viallon}

Main insights from permanent value capture instruments can be summarised as follows: communal, cantonal, and international tax competition induce an overall reduction of tax rates (Dafflon 2015). The latter is reinforced by the increased mobility of individuals across territories, that put forward the low costs of living in order to attract new inhabitants (Segessemann 2016). Therefore, the capture of landowners' windfall profits is competing with other factors, such as territorial attractiveness, and local policies, which can favor "housing as a mean of wealth creation and economic boosterism" (Segessemann and Crevoisier 2016: 1401).

\section{Value capture in practice}

Two emblematic implementation cases of punctual value capture instruments are presented: the voluntary tax on added land value in canton Bern, and the extended land service tax in canton Vaud. The goal of this section is to reveal actors' strategies in implementing these instruments in a federal state like Switzerland.

\section{Voluntary tax on added land value created by zoning in canton Bem}

Since 1985, cantonal Bernese spatial planning legislation granted to the communes the possibility to levy part of the added value created by planning measures through a tax on added land valie created by zoning. As a reminder from the first section, the gains collected through this tax are primarily aimed to compensate landowners who suffered a loss of value from a biilding zone reduction, and thus enhance the capacity of authorities to implement land policy.

The present analysis deals with Oberaargau, a peri-urban region composed of 47 communes in canton Bern (Viallon 2016a). In a context of demographic and land price stagnation, institutional fragmentation, and strong communal autonomy in land use planning and fiscal matters, the implementation of nonmandatory value capture instruments failed in a wide number of cases. In fact, 20 years after canton Bern introduced the tax on added land value, only 18 communes in this region had implemented the tax in their building regulations.

The communes that introduced the tax are mainly those that have oversized building zones. According to federal legislation, building zones are over-sized when they exceed communal needs for the next 15 years (art. 5 SPA). The outstanding fact is that these communes introduced the tax only after the definition of their building zone, from the 2000 s onward. Consequently, the initial aim of the instrument - the collection of funds in order to financially compensate building zone reductions - could not be fulfilled, as subsequent zoning operations were very limited due to already over-sized building zones. This leads to an ironic situation, where the tax on added land value created by zoning was implemented in reaction to the problem it intended to solve in the first place. 
In cases where the instrument was implemented, the funds collected through the instrument served other purposes than building zone reduction: part of the funds provided by the instrument were used as a substitute for the land service tax: the money collected paid land service - sometimes the one directly benefitting the landowner - or other communal infrastructure. Further, local authorities were free to fix the land values used as the tax base. This led in certain cases to an effective taxation of 21 percent of the added land value instead of the 30 percent contractually fixed (Viallon 2016a).

Overall, the implementation of value capturing instruments on the communal level faced high reluctance because it directly challenged local interests of both landowners and communal authorities: the former perceiving the capture of part of their gains as 'robber barony', the latter being put under pressure by fiscal competition and territorial attractiveness.

\section{Extended land service tax in Vaud}

The definition of the extended land service tax in'canton Vaud's legislation occurred in 2011 (art. 4B LICom). Since that year, the instrument's use has spread across a wide number of urban communes, in particular in the agglomeration of Lausanne. The case of the redevelopment of Malley, an industrial brownfield in the center of the agglomeration that has lost part of its former land uses, is of particular interest, because of the implementation of the tax on public and semi-public landowners: the ownership structure to be regulated by the future local development plan Malley-gare is composed of Lausanne, the urban center of the agglomeration $(130,000$ inhabitants), and of the Swiss Federal Railways. The land is located on the communal territories of Renens and Prilly, two smaller neighbor towns $(20,000$ and 10,000 inhabitants, respectively). Until today, legal uncertainty exists on the necessity for public landowners to pay the tax. The present case shows how the (semi-)public landowners used a set of policy resources in order to minimise the amount of value taxed (Viallon 2016b).

Malley's outstanding location in the center of the agglomeration, between the train lines and a subway line, and the reduced industrial activity present on site - the public gasworks closed in 1977, and the slaughterhouse closed in 2002 - led to the elaboration of several architectural comperitions and master plans in order to redevelop the area. Most important, the canton obtained federal funding for the construction of a regional train stop adjacent to the area, thus pushing towards land redevelopment.

Turning to the implementation of the extended land service tax, cantonal law states that authorities and their subordinated entities, as well as private entities working in the public interest (such as pension funds, churches, social security funds, health care funds, nonprofit moral persons working in culture) are exempted from the tax (art. $90 \mathrm{LI}) .^{5}$ Therefore, Lausanne and the SBB would be considered exempted from the tax. However, uncertainty prevailed on the objectives pursued by the two landowners: are these in the public interest or not? Both Lausanne and the SBB intended to lease their land 
to private developers through a building right, and neither the provision of surfaces for activities nor for housing are legally recognised of public interest.

Nevertheless, the question was not settled, and both the communes and the landowners mandated a legal expertise in order to clarify the matter. As one could have expected, both parties received contradictory legal advice leading to a stalemate. Instead of publicly exposing their divergences and losing time in front of a court, the actors agreed to negotiate the amount that would be paid.

The criteria to be used for fixing the amount of tax to be paid depended on the future uses of the buildings (housing being more expensive than activities due to the schools that are linked to it), but also on other factors, such as soil pollution: these costs had a significant impact on the project development, as landowners have the legal obligation to remediare the heavily polluted soils. In order to reduce remediation costs, authorities and landowners mandated several soil expertises determine the location and depth of pollution, and thus provide a wide amount of information allowing first to estimate excavation and remediation costs, and second to adapt the location of constructions within the development plan as well as their type (e.g. limitation of underground constructions). But the calculation of remediation costs, and of those linked to the development, required an organisational capacity that the territorial communes did not have, or at least did not allocate to the project. Consequently, an information asymmetry between authorities and landowners appeared, and the latter used it during negotiations in order to inflate costs linked with remediation and development and thus keep the taxed amount at the lowest level possible.

Another result of negotiation, which is possible by law, is the five-year delay granted to landowners for the payment of the extended land service tax, once the first building permit is delivered.

The negotiations' financial result, in particular the amount of value captured, depends on how the added value and the costs are calculated (Table 5.1). If one considers solely the extended land service tax, the instrument captured 2.9 percent of the added land value induced by the local development plan Malley-gare (Table 5.2). If one considers the extended land service tax jointly with the railway underpass, which is not part of regular land service according to federal legislation (and as a consequence financed through the added value captured), then the amount of added value taxed corresponds to 17.6 percent of the overall added land value created by zoning.

If one considers that the extended land service tax solely applies to the part of the local development plan that belongs to the semi-public landowner $\mathrm{SBB}$ (in the hypothesis that Lausanne, as public landowner, is exempted from the tax), then the amount of added land value taxed is around 8 percent. If the costs of the railway crossing are included in the calculations, then the percentage of value capture increases up to 22 percent. 
Table 5.1 Surfaces and gross floor areas of the local development plan Malley-gare (Viallon 2016b)

\begin{tabular}{|c|c|c|c|}
\hline Surfaces and densities & Total & CFF & Lausamne \\
\hline $\begin{array}{l}\text { Constructible ground surface of the } \\
\text { local development plan }\end{array}$ & $10,600 \mathrm{~m}^{2}$ & $7,551 \mathrm{~m}^{2}$ & $8,665 \mathrm{~m}^{2}$ \\
\hline Old gross floor area & $15,200 \mathrm{~m}^{2}$ & $7,100 \mathrm{~m}^{2}$ & $\begin{array}{r}8,100 \mathrm{~m}^{2} \\
32,000 \mathrm{~m}^{2}\end{array}$ \\
\hline New gross floor area & $52,500 \mathrm{~m}^{2}$ & $20,500 \mathrm{~m}^{2}$ & \\
\hline
\end{tabular}

Table 5.2 Land values, costs and taxes in the local development plan Malley-gare in the landowners' perspective (Viallon 2016b)

\begin{tabular}{ll}
\hline Values and costs & Total \\
\hline Old land value & $10.0 \mathrm{M} \mathrm{CHF}$ \\
New land value & $34.4 \mathrm{M} \mathrm{CHF}$ \\
Added land value & $24.4 \mathrm{M} \mathrm{CHF}$ \\
Planning costs & $0.3 \mathrm{M} \mathrm{CHF}$ \\
Remedjation costs & $2.4 \mathrm{M} \mathrm{CHF}$ \\
Connection tax & $0.7 \mathrm{M} \mathrm{CHF}$ \\
Land service tax & $2.1 \mathrm{M} \mathrm{CHF}$ \\
Railway underpass & $3.6 \mathrm{M} \mathrm{CHF}$ \\
Extended land service tax & $0.7 \mathrm{M} \mathrm{CHF}$ \\
\hline Estimated annual rent on building right & $4.5 \% \times 34.4 \mathrm{M}=1.55 \mathrm{M} \mathrm{CHF}$ \\
\hline
\end{tabular}

If the extended land service tax had been fully applied (30 francs per square meter for activities, and 140 francs per square meter for housing), 3 million francs would have been collected, and a taxation percentage of 12 percent (respectively 27 percent if one includes the railway underpass) could have been achieved.

Notwithstanding the percentage of taxation considered, this case has showed that a wide part of the added valued created by authorities remains in the hands of the landowners. In facr, using a capitalisation rate of 4.5 percent - a common rate for publicly attributed building rights (Cour des comptes du canton de Vaud 2011) - value captured by authorities is recovered through the land rent within three years.

\section{Effectiveness, practicability, and legitimacy of punctual value capture tools}

The two value capture instruments presented above provide a set of insights to be discussed and compared based on the criteria of practicability, effectiveness, efficiency, and legitimacy.

The empirical analysis of the tax on added land value and of the extended land service tax has shown a set of elements. In terms of practicability, we 
learned that the legal definition and choice of implementation of land policy instruments at local level reduces their chances to be used by authorities, and facilitates the circumvention of the instruments' initial purposes by landowners. Circumvention strategies are evident in the case authorities do not have a clear and explicit legal basis, but also occur when the instruments' modalities are unclear: for example, the tax base, as well as the percentage or monetary value of the tax, should be explicitly defined in regulation in order to reduce loopholes. As we have seen in the Bernese case, the tax on added land value requires precise information on land values before and after the zoning operation, which are not systematically available in Switzerland, and whose collection involves administrative costs. The Vaud case showed that the extended land service tax requires information on the production costs of communal infrastructure, but also on the production costs of the landowner/developer. Information asymmetry in favor of the landowner or developer tends to reduce the instruments' potential effects. And the provision of such information requires shared information between actors, but also personnel.

But exhaustive and stringent regulations, available information, and personnel are not enough to guarantee the instruments' effectiveness. Both instruments capture part of the land rent and redistribute it to other (land) policy objectives. Therefore, their effects on land depend on how the funds they collect are used. The Bernese tax on added land value created by zoning has shown that the implementation of compensation instruments at local scale face high controversy, both due to landowners and authorities. This issue was however solved with the 2014 revision of the federal spatial planning act, which has now defined the instrument as mandatory. Nevertheless, the collection of the tax on the cantonal level is incongruent with the scale of the problem it intends to solve, namely the reduction of over-sized building zones, which is a typically Swiss land policy issue. These over-sized building zones are mainly present in peri-urban cantons, and no inter-cantonal redistribution of the funds collected is planned (for example, between urban and peri-urban or mountainous cantons). As a whole, the tax on added land value created by zoning and the funds captured enhances authorities' margin of maneuver when adapting land policy, and in particular zoning plans, to socio-economic changes. Thus, it allows to reduce the gap between zoning and effective land use and fosters a more economic use of land. The extended land service tax provides a mean for funding public infrastructure that benefits the neighbourhood and the wider urban agglomeration. It passes part of the costs of urbanisation initially carried by local authorities on to the landowners. The instrument's effects on land depend on local polirical objectives (urban growth, reuse of brownfields, etc.), but are not tackled directly by the instrument.

In terms of efficiency, the tax on added land value created by zoning has moderate administrative costs (due to value assessment) and potentially a high punctual financial return, depending on the percentage of windfall 
profits taxed. A similar reasoning can be applied to the extended land service tax, although the tax as defined by canton Vaud limits the effective amount to be captured to 50 percent of the costs of infrastructure whose construction is due to the increase of development rights. The method used in order to calculate the amount due for each type of infrastructure (schools, kindergartens, green spaces, bus stops) refers to an average price paid per person by the commune over a 15 -year period for making the different services available.

One could argue that it could be easier to capture the added value through durative value capture instruments, such as the land tax or the income tax. In the absence of detailed analysis on the instruments' perceptions hold by policy makers, we can hypothesize that whereas a tax increase would produce highly visible changes in the communal budget and require an addjtional fiscal effort from all communal contributors, the tax on added land value and the extended land service tax are applied in a far less visible manner on very specific landowners who are granted substantial development advantages. The very limited implementation of the tax on added land value in Oberaargau's communes shows the lack of acceptance the instrument faces. The 40-year gap between the instrument's initial proposal in federal legislation (1974), and its mandatory definition (2014) further reveals how vested landowners and financial interests are to land property income.

In regard to the taxes' legitimacy, the lack of clear attribution of the funds reduces the acceptance of value capture tools, whereas the specific allocation of funds (for example, in a perimeter where it benefits the landowners) eases their acceptance. This issue becomes salient when considering that in canton Vaud, the extended land service tax was inirially used withour any legal basis because it leads to the emergence of joint interests between developers (to additional rights) and authorities (to more captured value).

Prioritising land uses with a high added economic value also leads to the eviction of uses with lower added economic value. Therefore, value capture should be not an objective per se. It is the question of the objectives of value redistribution, and of value control, that are central to land policy. The examples from canton Vaud show that value capture instruments whose funds are allocated to a specific and spatially defined (preferably local) purpose - and produce low redistributive effects - are more legitimate than those meant to achieve general objectives in nonspecified spatial perimeters that produce high redistributive effects. Hereby, they confirm the key role of redistribution inherent to all political processes (Schneider and Ingram 1990).

In Switzerland, the legal amount of rent that a property titleholder is entitled to is not setrled legally. In a 1979 decision on the constitutionality of levying land value increments due to zoning (BGE 105 Ia 134), the Federal Tribunal solely stated that the legal guarantee of ownership obligates the legislator to protect the substance of property and the possibility to increase wealth. This leaves a wide margin of maneuverability to future political choices, and to the appropriation or control of rent by the actor(s) and for 
the purpose(s) considered the most legitimate. As prospective thought for future (re-)development projects, the implementation of the tax on added land value that, in Switzerland, will now apply to all new building zones defined in the future, and that will capture 20 percent of value increment, does not appear as problematic, in particular if compared to the percentage of value capture that prevails in other countries (Altermann 2012).

\section{Notes}

1 Federal Spatial Planning Act (SPA) (Ratmplanungsgesetz, RPG) of 22 June 1979, SR 700 .

2 For reference, a square meter of gross floor area in an urban center around Lake Geneva, as in the case of Malley, is around 3,100 francs per square meter for activities and 2,500 francs for housing.

3 An additional wealth tax considering the entirety of wealth and not only land property exists in certain cantons and is to be added to the land property tax. In 2006 , the fiscal revenues it generated were around 2 billion francs.

4 Loi vaudoise du 5 décembre 1956 sur les jmpôts communaux (LICom), SR-VD 650.11 .

5 Loi vaudoise du 4 juiller 2000 sur les impôts cantonaux (LI), SR-VD 642.11.

\section{References}

Altermann, R. (2012) Land use regulations and property values: The "Windfalls Capture' idea revisited, int Brooks, N., Donaghy, K. and Knaap, G.-J. (eds) The Oxford handbook of urban economics and plaming, Oxford Unjversity Press, Oxford.

Berta, E. (2016) Nyon ou la recherche de l'équilibre par les conventions, Collage, 2016(3), 16-20.

BSS (2011) Konzepte zur Bauzonenverkleinerung. Abklärung der monetären Folgen und der Wirksankeit ton vier verschiedenten Konzepten, Schlussbericht zuhanden des Bundesamtes für Raumentwicklung (ARE), Basel.

Cervero, R. and Murakami, J. (2009) Rail and property development in Hong Kong: Experiences and extensions, Urban Sttidies, 46(10), 2019-2043.

Cour des comptes du Canton de Vaud (2011) Droits de superficie octroyés par les collectivités publiques vaiudoises, rapport numéro 19 du 13 décembre 2011, Lausanne.

Dafflon, B. (2015) Panoranta Des Impôts Suisses. Du Local Au Fèdéral, Entre Equité et Concurrence: Quels Enjetrx?, Domaine public, Lausanne.

Harvey, D. (1982) The limits to capital, Basil Blackwell, Oxford.

Nahrath, S. (2005) Le rôle de la propriété foncière dans la génèse et la mise en oeuvre de la politique d'améagement du territoire: quels enseignements pour la durabilité des aménagements urbains? in: Da Cunha, A., Knoepfel, P., Leresche, J.-P. and Nahrath, S. (eds) Enjettx du développement urbain durable. Transformations urbaines, gestion des ressources et gouvernance, Presses polytechniques universitaires romandes, Lausanne, 299-328.

Poldervaart, P. (2016) Abgabe schafft grünen Mehrwert für alle, Collage, 2016(3), 13-15. 
Schneider, A. and Ingram, H. (1990) Behavioral assumptions of policy tools, The Journal of Politics, 52(2), 510-259.

Segessemann, A. (2016) De La Production à La Consommation: Le Rôle de l'économie Résidentielle Dans Le Développement Régional, Université de Neuchâtel.

Segessemann, A. and Crevoisier, O. (2016) Beyond Economic Base Theory: The Role of the Residential Economy in Attracting Income to Swiss Regions, Regional Studies, 2016, 1-16.

Steuerverwaltung des Kantons Bern (2009) Erläuterungen zum steuerlichen Bewertungsystem von Grindstiicken und Liegenschaften im Kanton Bern, March, Bern.

Viallon, F.-X. (2016a) Implementation of redistributive land policy instruments in urban spaces: The case of Oberaargan (1990-2014), Working paper de l'IDHEAP, 2016(6), Lausanne.

Viallon, F.-X. (2016b) Implementation of redistributive land policy instruments in urban spaces: The case of Malley, Working paper de l'IDHEAP, 2016(7), Lausanne.

VLP-ASPAN (2015) Prélèvenent de la plis-wahue dans les différents cantons, état au 03 décembre 2015, Bern.

Walrert, F, Pütz, M., Böni, R. and Seidl, I. (2010) Fiskalische Instrumente unt Flächeninansprtichnabnte, Eidgenössische Forschungsanstalt für Wald, Schnee wnd Landschaft WSL, Bundesamt für Umwelt BAFU, Bern.

Wüest und Partner (2006) Immo-Monitoring, 2006(3), Zürich. 


\section{A Dutch perspective on added value capture: how far can you go?}

Erwin van der Krabben

In 1879 Henry George advocated, in his famous work Progress and Property (George 1879), the introduction of a land value tax - also referred to as a 'single tax' on land. Before him, Adam Smith had already called it 'the perfect tax' (Smith 1776; Webb 2013) because of its economic effects. George argued that because the supply of land is fixed and its location value is created by communities and public works, the economic rent of land is the most logical source of public revenue. While most taxes distort economic decisions and suppress beneficial economic activity, land value tax is payable regardless of how well or poorly land is actually used. Noble Prize winner William Vickrey believed that

removing almost all business taxes, including property taxes on improvements, excepting only taxes reflecting the marginal social cost of public services rendered to specific activities and replacing them with taxes on site values, would substantially improve the economic efficiency of the jurisdiction.

(Vickrey 1996: 603)

Despite the strong economic arguments in favor of land value tax as the main - or single - revenue source for public finance, and despite (ongoing) debates in many countries around the world to introduce land value tax, only few countries actually implemented land value tax (but never as a single tax), including some states in Australia, Hong Kong, Taiwan, Colombia, Denmark, and Mexico (Andelson 1971).

The introduction of a land value tax in Switzerland can be related to these theoretical discussions. The Swiss case is interesting from at least two different perspectives. First, the introduction of - or better, attempts to introduce - a land value tax has led to political controversy in other countries as well. To place the Swiss case in an international context, I will briefly refer to the (political) objections that arose after related proposals to "cream off' the planning gain, which arises when permission to develop land is granted, in the UK and the Netherlands. Second, the Swiss case of introducing a land 
value tax system provides an interesting insight into the practical aspects of implementing such tax.

Before introducing the UK and Dutch political debates with regard to taxing development gain, it is useful to distinguish this tax on development gain (or land value tax) from (1) developer contributions (or obligations) to plan-related infrastructure costs (from which the developer will benefit directly) and (2) property tax. Most countries use some kind of system to make developers contribute to the infrastructure costs related to a plan. They are often discussed in a technical sense, but the political dispute about them is usually limited. Property tax is a general tax based on property value and is not meant to cream off development gain (although they do to a certain extent, if there is a property value increase because of a development). ${ }^{1}$ Perhaps the most documented dispute over taxing development gains took place in the 1940s in the UK after publication of the Uthwatt Report in 1942. The Uthwatt Committee discussed among other things the introduction of a betterment levy to capture the planning gain - quire similar to the Swiss land value tax. A betterment levy was introduced in the 1947 Town and Country Planning Act. However, the political controversy about the new regulation became clear soon after, when the subsequent Conservative government immediately decided to abolish it by passing the 1954 P'lanning Act. Internationally less known is the political crisis that developed in the Netherlands in 1977, after incompatible views had arisen with respect to land policy between the Labour Party and the Christian Democrats that formed a coalition at that time. The debate was not about introducing a land value tax, but about a related theme: the compensation to be paid in case of expropriation. While the Labour Party wanted a compensation based on the value of the land in its original use (the planning gain as the result of the government decision to change the use of the land would go to the state), the Christian Democrats did not want to change the existing regulation that prescribes compensation based on the market value of the land (the planning gain would remain with the owner that would be expropriated). The coaljtion partners couldn't agree on the method to define compensation (which added up to some other disagreements within the coalition) and decided to step down. Compensation for expropriation would continue to include planning gain. Since then the issue has hardly been touched upon in Dutch politics. In 2008 a new land law was introduced, but this land law was meant to offer a legal basis for charging developer obligations and did not touch upon the issue of taxing development gains. ${ }^{2}$ Political debate regarding the present revision of the expropriation law - as part of the law on land and property ownership (Aanvullingsivet Grond en Eigendom), which will replace both the 2008 land law and the current expropriation law, which will be, in turn, part of the new Law on the Environment (Omgevingstuet), expected to be implemented in 2019, also ignores this topic. My impression is that in the Netherlands - though the country is sometimes considered a 
planning paradise, with strong planning legislation - a similar proposal to introduce a land value tax, as in Switzerland, is unthinkable, because of the legal view that all value increase, including planning gain, rightfully belongs to the properry owner.

The implementation of a land value tax - as probably any other tax - also raises questions with respect to the practicability, effectiveness, efficiency, and legitimacy of such a tax. The Swiss case illustrates quite convincingly that these aspects may cause problems. For instance, it seems to me that the practice in some places to informally negotiate a lump sum contribution to finance infrastructure beyond land servicing costs makes the value capture system quite inscrutable. Moreover, an efficient and fair land value tax system requires precise information on land values before and after a change in the zoning plan. According to Viallon, such information is not systematically available in Switzerland, and high administrative costs will be involved when a more standardized system would be introduced. And finally, it is claimed that legitimacy issues may appear. The use of land value tax may bring local authorities to prioritize land uses with a high added economic value, because it will give them higher revenue compared to uses with lower added value.

The 'solution' sought in the Netherlands with respect to practicability issues regarding charging development contributions (which is different from a land value tax) has been to make it as transparent as possible. All types of costs that can be charged to private developers have been described. Before plan approval can take place, all plan-related costs must be covered. The extent to which private developers must contribute to these costs depends on three criteria: profitability, proportionality, and accountability. In addition, a maximum has been set to the size of the contribution: it can never exceed a level that would lead to a financial loss for the private developer. In such a situation, the municipality must find other ways to cover these extra costs (or decide not to approve the plan). Developer contributions to plan-related infrastructure can be forced, according to the law, but only when a voluntary agreement cannot be reached. This provides possibilities for negotiations between the municipality and private developers (which are not very transparent), which may include adjustments to the real estate program (density, housing mix, etc.) and/or adjustments to the infrastructure. After the introduction of this legislation in 2008, both municipalities and private developers seemed to be more or less happy with the system. It wasn't until a few years later that the first problems arose. While the traditional comprehensive development plans usually made it possible to calculate all infrastructure costs in advance, the 'organic', bottom-up developments that have become more dominant now in urban transformation projects often do not allow calculating these costs in advance because it is frequently unknown at the start of the plan what will be developed. Another problem is that, even if the municipality would be able to define all necessary infrastructure works, it would be obliged to guarantee covering the 
costs itself because it is unknown who will develop. The aforementioned 'land and property ownership law' offers some solutions to this. However, as the minister responsible for spatial planning has stated herself in the explanatory memorandum for the draft version of the law, another problem remains to be solved. Where Dutch cities in the past usually were able to raise sufficient revenue for covering infrastructure costs by relying on the combination of income from land sales, contributions by private developers and national government subsidies, this has become quite uncertain for the future (with possibly large variation among cities regarding the size of the problem). Income from land sales is substantially lower than it used to be, national subsidies for urban renewal are no longer available, and with (less profitable) urban transformation projects now becoming more dominant, contributions by private developers may decrease as well. The minister acknowledges the problem, but has not yet suggested any solutions to it.

\section{Notes}

1 There is also much international debate about property tax, particularly in developing countries, mainly in relation to public finance and municipal fiscal health, but I leave that aside.

2 Dutch municipalities, however, made use of another strategy to capture planning gain. By the commonly used public land development model they were able, as landowners, to keep most of the planning gain. Since 2008 (the global economic and real estate crisis), municipalities have become much mote reluctant to use this development model because of the financial risks involved.

\section{References}

Andelson, R.V. (1971) Land-value taxation around the world, Wiley Blackwell, Hoboken, NJ.

George, H. (1879) Progress and poverty, The Country Live Press, New York.

Smith, A. (1776) The wealth of nationts, Wordsworth Editions Ltd.

Vickrey, W. (1996) The corporate income tax in the U.S. Tax System, Tax Notes, (73), 597-603.

Webb, M. (2013) How a levy based on location values could be the perfect rax, Financial Times (accessed 23 March 2017). 


\title{
A British perspective on added value capture: ups and downs during its history
}

\author{
Janet Askew
}

In the UK, there is a long history of using planning instruments to tax betterment and capture value that comes about as a result of changing the use of land (via planning policy or planning permission). Alterman (2012) refers to Britain as the 'world's former laboratory of betterment-capture instruments'. Indeed, the power to use such instruments was first introduced in 1932 , since which time it has been evolving. This is particularly pertinent to the Swiss case of value capture, which was first mooted in 1974, but has not yet been implemented across the whole country (see $\rightarrow$ Viallon). It is not an easy instrument to devise. Methods and regulations to capture value continue to be debated in many countries, with much experimentation with new approaches (Hobma et al. 2014). This is true of the UK, and current regulations employ a mixture of negotiation and a financial levy.

The question is, how much does the land value capture instrument contribute to land scarcity? It is important to comprehend some fundamental differences between the English planning system and those of other countries to fully understand how the instruments work. This is relevant to the debate on land value capture instruments. The instruments are created by central government and apply to the whole country. How are they regulated? What is the process by which they are applied? The Town and Country Planning Act of 1947, which is the basis upon which planning law is based, nationalized development rights (Booth 2003), meaning that individual property rights do not assume such great importance in relation to town planning as elsewhere in the world. Two other features distinguish the British planning system. The first is the centralisation of planning regulations that have to be adhered to by planning authorities; local regulations cannot be made. In this, England differs considerably from the Swiss system, where local regulations and local taxes can be imposed. Second is the requirement for a development plan to be produced and, after a lengthy process of consultation, adopted as a statutory document. This is the primary material consideration for decision-making. There is no legally binding plan. The main difference between the English system and others is the point at which the decision to build is taken. The decision is discretionary; the absence of an up-to-date land use plan does not eliminate the ability to develop, rather it means that 
other material considerations are taken into account before permission to develop is granted, resulting in considerable negotiation during the process. The development plan often includes value capture policies that enhance the ability of the local authority to seek developer contributions, and negotiation is often protracted.

The history of land value capture in England has meant that there have been many attempts over the past 80 years to introduce methods of taxing betterment, with successive governments repealing old laws and introducing new ones. The property boom of the early 1970 s saw an increase in the use of planning gain and the idea of capturing value was encapsulated in Section 52 of the Town and Country Planning Act 1971. Debate and controversy have continued ever since, with numerous changes to the instruments, and successive governments have tried to find a way to regulate for a fair system to overcome perceptions that there was widespread extortion in planning gain (Cullingworth and Nadin 2006). During the ensuing years, there was increasing use of planning gain agreements, with considerable objection by developers and communities to their implementation. In particular, the agreements were inconsistent, not transparent, and not measured. In order to regularise them, the Town and Country Planning Act 1990 included a new Section 106 that related to planning gain agreements, accompanied by various statutory orders that laid down tests to ensure fairness, necessity, and proportionality of the gains sought.

Despite this, debate and objections continued and, in particular, there was concern that the Section 106 agreements were overly complex, resulting in lengthy and costly negotiations (DCLG 2008). Such criticisms raised questions concerning their effectiveness, integrity, and sustainability. The legitimacy of the negotiated outcome based upon both the appropriateness of the proposed agreement was queried, as well as the ability to directly link the settlement with the proposed development (Moore and Purdue 2012). Challenges to the courts to interpret and mediate unreasonable demands were increasing, and the process was becoming expensive (Askew and Sheppard 2014).

More specifically, two aspects to planning agreements began to crystallise. The first is linked to the idea that the uplift in land value should be taxed. This relates to early ideas about betterment due to changing designations of the use of land, and is called 'punctual' value capture by Viallon. In England, successive governments have mostly avoided direct land taxes, leaving any uplift in value to be achieved by negotiation.

The second aspect might be termed 'cost recovery', which became more prevalent with the cutbacks in public sector funding, resulting in local authorities needing to secure finance for associated infrastructure, sometimes directly associated with a new development, sometimes not. During the 1990 s and early 2000 s, demands for cost recovery grew, including the ability for local authorities to collect cash directly. Further evidence that the system was not working very well was confirmed when local authorities 
were found to be underspending and sitting on the surplus, despite serious shortages of funds for public services.

To overcome these issues, in particular to standardise demands for social housing and infrastructure, and to clarify the use of planning gain, a law in the Planning Act 2008 introduced one new instrument - the Community Infrastructure Levy (CIL). It amended the use of the Section 106 agreement with regard to its use for affordable and social housing provision.

The Community Infrastructure Levy is more akin to a development tax and requires the local authority to prepare a mandatory charging schedule, accompanied by a 'Regulation 123 List' of developments for which the levy will be used. While the list states what the Community Infrastructure Levy is collected for, it does not necessarily apply to infrastructure directly associated with the development upon which the tax is levied. There are some limited powers to allow for different tax percentages to be set locally, so that poorer areas wanting to encourage investment can set their Community Infrastructure Levy at zero. The fact that the money is not used directly for the benefit of the actual development, 'but as a contribution towards new infrastructure across the council area has already attracted criticism from developers. This was an issue in the Swiss canton Vaud. To date, there has been a lack of ambition on the part of local authorities in England, and the lists produced contain a preponderance of road schemes and traffic improvements, although they are able to include new schools, parks, flood defences, or social care facilities (Askew and Sheppard 2014). As an incentivisation measure, a portion of these funds is allowed to be given co smaller communities who are preparing a neighbourhood plan.

Section 106 agreements remain flexible, are not mandatory, are open to negotiation, and are only for related off-site works and affordable housing. Long-standing objections of uncertainty have not been overcome. As a result, there continues to be debate and concern over the use of value capture and cost recovery instruments, with developers objecting to the imposition of two separate 'taxes'. Of great relevance to this is the fact that for the first time, the viability of a development has become a material consideration in decision-making. The National Planning Policy Framework (DCLG 2012) has a policy that allows developers to argue that a development would be rendered unviable if Section 106 agreements are deemed to be unreasonable, particularly in the area of affordable housing. Viability for developers is a crucial part of the government's housing strategy (Housing White Paper, DCLG 2017) and this affects the local authority's ability to achieve affordable housing in a development. Many developers simply argue that they cannot afford the social element.

Unlike in Switzerland, developers and planning authorities in England are accustomed to the use of different instruments for the capture of value. While there is considerable debate about how best to do this, it is accepted by all stakeholders that these instruments will be applied. As a result, there is no avoidance of them and although arguments persist in negotiations, their desired achievements are compromised by viability issues. 
There is little evidence to suggest that value capture instruments in England are the cause of land shortages, nor that they in any way exacerbate scarcity of land. England has a long history of cost recovery and betterment taxes and, for over 80 years, it has been devising and amending ways of recovering the uplift in value of land. Developers assert that there is a scarcity of land in England, but they do not blame instruments of value capture. Rather, they blame the bureaucracy of planning for delays in achieving permission to develop, protracted negotiation being one of their main complaints. But their ire is mainly directed at models that constrain city growth, most particularly countryside and green belt designations.

Land value capture is not a staric instrument in England. The latest instruments are being scrutinised for their effectiveness, and reviews and policy statements are common. What is certain is that planning gain instruments are not currently demonstrating success in helping to resolve the housing crisis.

\section{References}

Alterman, R. (2012) Land use regulations and property values: The 'Windfalls Capture' idea revisited, in: Brooks, N., Donaghy, K. and Knaap, G. J. (eds) The Oxford handbook of urban cconomics and planting, Oxford University Press, Oxford, 755-786.

Askew, J. and Sheppard, A. (2014) England, in: Hobma, F. (ed.) Internationale vergelijking financiering en kostenverbaal bij organische gebiedsontwikkeling, Report for the Ministry of Infrastructure and Environment of the Netherlands, TU Delft, The Netherlands, 63-106.

Booth, P. (2003) Planning by consent - the origins and nature of British development control, Routledge, Oxford.

Cullingworth, B. and Nadin, V. (2006) Town and eountry planning in the UK, Routledge, Oxon.

DCLG (2008) The community infrastructure levy, HMSO, London.

DCLG (2012) The national planing policy framework, HMSO, London.

DCLG (2017) Fixing our broken bousing market, White Paper, HMSO, London.

Hobma, F., Askew, J., Mitschang, S., Santing, J., Schwarz, T., Sheppard, A. and Verbist, S. (2014) Internationale vergelijking funanciering en kostenverhaal bij organische gebiedsontwikkeling (International comparison of funding and cost recovery in organic area development). Technical Report. TU Delft.

Moore, M. and Purdue, M. (2012) A practical approach to planning law, Oxford University Press, Oxford. 